http://dx.doi.org/10.11646/phytotaxa.143.1.1

\title{
A taxonomic revision of the tribe Pleuroweisieae (Pottiaceae, Bryophyta) in South America
}

\author{
MARÍA J. CANO \& JUAN A. JIMÉNEZ \\ Departamento de Biología Vegetal, Facultad de Biología, Universidad de Murcia, Campus de Espinardo, 30100-Murcia, Spain; \\ e-mail:mcano@um.es
}

\begin{abstract}
The genera Anoectangium, Gymnostomum, Hymenostylium, and Molendoa, included in the tribe Pleuroweisieae, are studied in South America. After a thorough revision of both herbarium material and our own recent collections from the area, we recognize eight species among these genera. In Hymenostylium, $H$. recurvirostrum and $H$. aurantiacum are accepted, the latter newly reported for the territory. Hymenostylium contextum and H. kunzeanum are placed in the synonymy of $H$. recurvirostrum and Weissia stillicidiorum and Hydrogonium taylorii of $H$. aurantiacum. In Gymnostomum, only G. calcareum is recognized in South America. Gymnostomum tenerrimum is considered a synonym of G. calcareum and G. aeruginosum is tentatively excluded from the area. In Molendoa, M. sendtneriana and M. peruviana comb. nov. are recognized. Anoectangium calidum, Molendoa andina, M. subobtusifolia, and Trichostomum glaucoviride are proposed as synonyms of M. sendtneriana and Anoectangium herzogii, A. platyphyllum, A. lechlerianum and Triquetrella cucullata of M. peruviana. Molendoa fuegiana and M. guentheri are excluded from Molendoa and considered synonyms of Didymodon australasiae. In Anoectangium, A. aestivum, A. euchloron and A. stracheyanum are accepted. Anoectangium brachyphyllum and Zygodon tenellus are treated as synonyms of $A$. euchloron, A. pflanzii of A. aestivum and A. lechlerianum var. laetior and Zygodon linearis of A. stracheyanum. Anoectangium herzogii, A. calidum, and A. lechlerianum var. limbatulum are excluded from Anoectangium. The first is considered conspecific with Molendoa peruviana and the rest with M. sendtneriana. The genus Tuerckheimia represented by T. guatemalensis is excluded from South America. Lectotypes for twenty two names (Anoectangium euchloron f. elata, A. herzogii, A. lechlerianum, A. lechlerianum var. laetior, A. lechlerianum var. limbatulum, A. patagonicum, A. pflanzii, A. sendtnerianum, A. sordidum, A. tenerrimum, Gymnostomum longirostre, G. recurvirostrum, Hymenostylium contextum, H. longopulvinatum, Molendoa fuegiana, Trichostomum glaucoviride, Triquetrella cucullata, Weissia stillicidiorum, W. venezuelensis, Zygodon excelsus, Z. linearis and Z. tenellus) are proposed. A key, descriptions, illustrations and distribution maps are provided for each species.
\end{abstract}

Key words: Anoectangium, Gymnostomum, Hymenostylium, lectotypes, Molendoa, new records, taxonomy, Tuerckheimia

\section{Introduction}

Pleuroweisieae was proposed as a subfamily of Pottiaceae by Limpricht (1886), and later treated as a tribe within Eucladioideae by Chen (1941). This latter author included three genera in the tribe Pleuroweisieae: Pleuroweisia Limpr. ex Schliephacke (1885: 359), Anoectangium Schwägrichen (1811:33) and Molendoa Lindberg (1878: 29), and seven in Eucladieae: Eucladium Bruch \& Schimper (1846: 93), Gymnostomum Nees von Esenbeck \& Hornschuch (1823: 112), Gyroweisia Schimper (1876: 36), Hymenostylium Bridel (1827: 81), Hymenostyliella Bartram (1939: 108), Reimersia Chen (1941: 62), and Tridontium Hooker (1840: pl. 148). Saito (1975), in his monograph of Japanese Pottiaceae, treated Chen's Eucladioideae as tribe Pleuroweisieae in the subfamily Pottioideae, including within it Leptodontieae, Barbuleae and Pottieae. According to Saito (1975), this tribe is characterized by the hardly differentiated basal laminal cells, plane basal leaf margins, the low gemmae-formation, and eperistomate or reduced peristome in the capsule. 


\section{Tuerckheimia guatemalensis Brotherus (1910: 1)}

In South America, this species was reported from a single locality in Brazil (Yano \& Barros 2004). After revision of the specimen kept at SP [Brazil, Mato Grosso, Munic. Alto Taquarí, ca $25 \mathrm{~km}$ à Sudeste da Cidade, estrada de acesso à Fazendas, córrego da Laje, 21 February 1996, Pietrobom da Silva et al. 3021 (SP)], it must be referred to Anoectangium euchloron. Therefore, T. guatemalensis must be excluded from the studied area.

\section{Acknowledgments}

This research was carried out with financial support from the Spanish "Ministerio de Ciencia e Innovación" (Project CGL2010-15959/BOS co-financied by FEDER and "Ramón y Cajal" subprogram co-financied by the European Social Fund). We thank the staff of the Botanical Museum of Córdoba (Argentina), University of Brasilia (Brasil), National Herbarium of La Paz (Bolivia), Botany Department, University of Concepción (Chile), National University of Loja (Ecuador), University of San Marcos of Lima (Peru) and National Herbarium of Fundación Instituto Botánico de Venezuela Dr. Tobías Lasser in Caracas (Venezuela) for their assistance during our field trips in South America, and A. Schäfer-Verwimp, P. Sollman and the curators of the herbaria cited in the text for assistance during our visit to the herbaria or the loan of specimens. We also thank D. Peralta, G. Suárez and H.J. Zündorf by diverse information about the localization of specimens and M. Price and for assistance with nomenclature matters. We also appreciate the valuable comments and suggestions of R.H. Zander, and other anonymous reviewer.

\section{References}

Allen, B. (2002) Moss flora of Central America, Part 2. Encalyptaceae-Orthotrichaceae. Monographs in Systematic Botany from the Missouri Botanical Garden 90: 1-699.

Arts, T. \& Sollman, P. (1998) A contribution to the moss flora of Ecuador. Tropical Bryology 14: 43-52.

Aziz, M.N. \& Vohra, J.N. (2008) Pottiaceae (Musci) of India. Bishen Singh Mahendra Pal Singh, Dehra Dun, India, 366 pp.

Bartram, E.B. (1936) New mosses from Argentina. In: Bauer, E. Musci Europaei et Americani Exsiccati 46, Appendix. $1-6$.

Bartram, E.B. (1939) Mosses of the Philippines. Philippine Journal of Science 68: 1-437.

Bartram, E.B. (1946) New mosses from Tierra del Fuego. Farlowia 2: 309-319.

Bridel, S.E. (1827) Bryologia universa seu systematica ad novam methodum dispositio, historia et descriptio omnium muscorum frondosorum huscusque cognitorum cum synonymia ex auctoribus probatissimis, vol. 2. J. A. Barth, Leipzig.

Brotherus, V.F. (1902) Bryales, in part. I (3). In: Engler, H.G.A. \& Prantl K.A.E. (eds.) Die Natürlichen Pflanzenfamilien. Engelmann, Leipzig, pp. 385-432.

Brotherus, V.F. (1910) Neue Laubmoosgattungen. Oefversigt af Förhandlingar, Finska Vetenskaps-Societeten 52A(7): $1-12$.

Brotherus, V.F. (1912) Musci frondosi. In: Perkins, J. (ed.4). Beiträge zur Flora von Bolivia. Botanische Jahrbücher für Systematik, Pflanzengeschichte und Pflanzengeographie 49: 170-233.

Brotherus, V.F. (1920) Contributions à la flore bryologique de l'Ecuador. Revue Bryologique 47: 1-16.

Brotherus, V.F. (1924) Musci (Laubmoose). 1. Hälfte. 10. In: Engler, H.G.A. \& Prantl, K.A.E. Die Natürlichen Pflanzenfamilien, ed. 2. Duncker \& Humblot, Berlin, 478 pp.

Brotherus, V.F. (1931) Neue exotische Laubmoose. Mitteilungen aus dem Institut für allgemeine Botanik in Hamburg 8: 399-406.

Bruch, P. \& Schimper, W.P. (1846) Fasc. 33-36. Brachyodus, Anodus, Seligeria, Blindia, Stylostegium, Hymenostomum, Weisia, Rhabdoweisia, Gymnostomum, Eucladium, Angstroemia, Arctoa, Cynodontium. In: Bruch, P., Schimper, W.P. \& von Gümbel, W.T. Bryologia Europaea. E. Schweizerbart, Stuttgart.

Cano, M.J. (2008) Taxonomic revision of Hennediella Paris (Pottiaceae, Bryophyta). Bryophytorum Bibliotheca 64: 1142.

Cano, M.J. \& Gallego, M.T. (2008) The genus Tortula (Pottiaceae, Bryophyta) in South America. Botanical Journal of the Linnean Society 156: 173-220. 
http://dx.doi.org/10.1111/j.1095-8339.2007.00739.x

Cano, M.J., Jiménez, J.A., Gallego, M.T. \& Jiménez, J.F. (2010a) Guerramontesia microdonta (Pottiaceae, Bryophyta) a new monotypic genus from South America. Systematic Botany 35: 453-460. http://dx.doi.org/10.1600/036364410792495953

Cano, M.J., Jiménez, J.A. \& Jiménez, J.F. (2010b) A systematic revision of the genus Erythrophyllopsis (Pottiaceae, Bryophyta). Systematic Botany 35: 683-694. http://dx.doi.org/10.1600/036364410X539772

Cardot, J. \& Brotherus, V.F. (1923) Botanische Ergebnisse der schwedischen Expedition nach Patagonien und dem Feuerlande 1907-1909. X. Les mousses. Kongliga Svenska Vetenskaps Academiens Handlingar 63(10): 1-174.

Chen, P.C. (1941) Studien über die ostasiatischen arten der Pottiaceae. I. Hedwigia 80: 1-76.

Churchill, S.P., Griffin III, D. \& Muñoz, J. (2000) A checklist of the mosses of the tropical Andean countries. Ruizia 17: $1-203$.

Costa, D.P., Pôrto, K.C., Luizi-Ponzo, A.P., Ilkiu-Borges, A.L., Bastos, C.J.P., Câmara, P.E.A.S., Peralta, D.F., BôasBastos, S.B.V., Imbassahy, C.A.A., Henriques, D.K., Gomes, H.C.S., Rocha, L.M., Santos, N.D., Siviero, T.S., VazImbassahy, T.F. \& Churchill, S.P. (2011) Synopsis of the Brazilian moss flora: checklist, distribution and conservation. Nova Hedwigia 93: 277-394. http://dx.doi.org/10.1127/0029-5035/2011/0093-0277

Cox, C.J., Goffinet, B., Wickett, N.J., Boles, S.B. \& Shaw, A.J. (2010) Moss diversity: a molecular phylogenetic analysis of genera. Phytotaxa 9: 175-195.

Dixon, N.H. (1927) Hymenostylium xanthocarpum (Hook.) Brid. The Bryologist 30: 106-109.

Dixon, N.H. (1933) The nomenclature on the Species Muscorum. Revue Bryologique et Lichénologique 6: 93-115.

Dusén, P. (1906) Beiträge zur Bryologie der Magellansländer, von Westpatagoien und Südchile. 4. Arkiv för Botanik utgivet av K. Svenska Vetenskapsakademien 6(8): 1-40.

Eckel, P.M. (2007) Hymenostylium. In: Flora of North America Editorial Committee (eds.) Flora of North America North of Mexico. Oxford University Press, New York, 27: 577-580.

Eckel, P.M. (2009) Hymenostylium jacksharpii (Bryophyta, Pottiaceae) of Central America is H. recurvirostrum var. insigne. Bulletin of the Buffalo Society of Natural Sciences 38: 5-11.

Eddy, A. (1990) A Handbook of Malesian Mosses. Vol 2. Leucobryaceae to Buxbaumiacea. Natural History Museum Publications, London, $256 \mathrm{pp}$.

Fife, A.J. (1995) Checklist of the mosses of New Zealand. The Bryologist 98: 313-337. http://dx.doi.org/10.2307/3243371

Fürnrohr, A.E. (1829) Sam. El. a Bridel-Brideri [...] Bryologia Universa [...] Vol. primum 1826 [...] Vol. secundum 1827 [...]. Flora 12: 1-60.

Gangulee, H.C. (1972) Mosses of Eastern India and Adjacent Regions, fasc. 3. Privately published, Calcutta, pp. 567830.

Geissler, P. (1985) Notulae bryofloristicae helveticae II. Candollea 40: 193-200.

Greville, R.K. (1830) Description of some new mosses discovered in South America by Dr. Gillies. Edinburg Journal of Natural and Geographical Science 2: 1-4.

Griffith, W. (1842) Muscologia itineris Assamici [I]; or, a description of mosses, collected during the journey of the Assam Deputation, in the years 1835 and 1836. Calcutta Journal of Natural History and Miscellany of the Arts and Sciences in India 2: 465-514.

Guerra, J. (2004) Pottiaceae: Gymnostomum, Gyroweisia, Hymenostylium, Leptobarbula. Sociedad Española de Briología, Murcia, pp. 7-22.

Guerra, J. (2006a) Hymenostylium. In: Guerra, J., Cano, M.J. \& Ros, R.M. (eds.) Flora Briofítica Ibérica, vol. 3. Universidad de Murcia, Sociedad Española de Briología, Murcia, pp. 42-44.

Guerra, J. (2006b) Gymnostomum. In: Guerra, J., Cano, M.J. \& Ros, R.M. (eds.) Flora Briofitica Ibérica, vol. 3. Universidad de Murcia, Sociedad Española de Briología, Murcia, pp. 32-39.

Guerra, J. (2006c) Anoectangium. In: Guerra, J., Cano, M.J. \& Ros, R.M. (eds.) Flora Briofitica Ibérica, vol. 3. Universidad de Murcia, Sociedad Española de Briología, Murcia, pp. 47-49.

Hampe, E. (1865) Prodromus florae Novo-granatensis ou énumétion des plantes de la Nouvelle-grenade. Annales des Sciences Naturelles; Botanique, sér. 5, 4: 324-378.

He, S. \& Khang, N.H. (2012) New records and updated checklist of the mosses of Vietnam. Tropical Bryology 34: 3288.

Hedwig, J. (1801) Species Muscorum Frondosorum. J.A. Barth, Lipsiae [Leipzig], 352 pp.

Hegewald, E. \& Hegewald, P. (1985) Eine Moossammlung aus Peru. III. Nova Hedwigia 41: 219-271.

Herzog, T. (1909) Beiträge zur Laubmoosflora von Bolivia. Beihefte zum Botanischen Centralblatt 26: 45-102.

Herzog, T. (1916) Die bryophyten meiner zweiten Reise durch Bolivia. Bibliotheca Botanica 87(1): 1-168.

Herzog, T. (1920) Die Bryophyten meiner zweiten Reise durch Bolivia. Bibliotheca Botanica 88: 1-33.

Herzog, T. (1924) Contribuções ao conhecimento da flora bryologica do Brasil. Arquivos de Botânica do Estado de São 
Paulo 1(2): 27-105.

Herzog, T. (1954) Zur Bryophytenflora Chiles. Revue Bryologique et Lichénologique 23: 27-99.

Higuchi, M. \& Nishimura, N. (2003) Mosses of Pakistan. Journal of the Hattori Botanical Laboratory 93: $273-291$.

Hill, M.O., Bell, N., Bruggeman-Nannenga, M.A., Brugués, M., Cano, M.J., Enroth, J., Flatberg, K.I., Frahm, J.P., Gallego, M.T., Garilleti, R., Guerra, J., Hedenäs, L., Holioak, D.T., Hyvönen, J., Ignatov, M.S., Lara, F., Mazimpaka, V., Muñoz, J. \& Söderström, L. (2006) An annotated checklist of the mosses of Europe and Macaronesia. Journal of Bryology 28: 198-267.

http://dx.doi.org/10.1179/174328206x119998

Hilpert, F. (1933) Studien zur Systematik der Trichostomaceen. Beihefte zum Botanischen Centralblatt 50(2): 585-706.

Hooker, W.J. (1819) Musci Exotici; containing figures and descriptions of new or little known foreign mosses and other cryptogamic subjects, vol. 2. Longman, Hurst, Rees, Orme, and Brown, London.

Hooker, W.J. (1840) Icones plantarum or figures, with brief descriptive characters and remarks, of new or rare plants, selected from the author's herbarium, vol. 3. Longman, Rees, Orme, Brown, Green, \& Longmans, London.

Ignatov, M.S. \& Ignatova, E.A. (2003) Moss flora of the Middle European Russia. Volume 1: SphagnaceaeHedwigiaceae. Arctoa 11(Supplement 1): 1-608.

Ignatov, M.S., Afonina, O.M. \& Ignatova, E.A. (2006) Check-list of mosses of East Europe and North Asia. Arctoa 15: $1-130$.

Ignatova, E.A. (2009) The genus Anoectangium (Pottiaceae, Bryophyta) in Russia. Arctoa 18: 167-176.

Iwatsuki, Z. (2004) New catalog of the mosses of Japan. Journal of the Hattori Botanical Laboratory 96: 1-182.

Jaeger, A. (1870) Adumbratio flore muscorum totius orbis terrarum. Part 1. Bericht über die Thätigkeit der St. Gallischen Naturwissenschaftlichen Gesellschaft 1869-1870: 245-299.

Jaeger, A. \& Sauerbeck, F. (1879) Adumbratio flore muscorum totius orbis terrarum. Part 9. Bericht über die Thätigkeit der St. Gallischen Naturwissenschaftlichen Gesellschaft 1877-1878: 257-514.

Jiménez, J.A., Cano, M.J. \& Jiménez, J.F. (2012) Taxonomy and phylogeny of Andina (Pottiaceae, Bryophyta): a new moss genus from the tropical Andes. Systematic Botany 37(2): 293-306. http://dx.doi.org/10.1600/036364412X635359

Köckinger, H. \& Kučera, J. (2011) Hymenostylium xerophilum, sp. nov., and H. gracillimum, comb. nov., two neglected European mosses and their molecular affinities. Journal of Bryology 33(3): 195-209. http://dx.doi.org/ 10.1179/1743282011Y.0000000012

Kürschner, H. \& Frey, W. (2011) Liverworts, Mosses and Hornworts of Southwest Asia (Marchantiophyta, Bryophyta, Anthocerotophyta). Nova Hedwigia, Beiheft 139: 1-240.

Limpricht, K.C. (1885-1889) Die Laubmoose Deutschlands, Oesterreichs und der Schweiz. Abth. 1. Eduard Kummer, Leipzig.

Lindberg, S.O. (1863) Bidrag till mossornas synonymi. Öfversigt af Förhandlingar: Kongl. Svenska VetenskapsAkademien 20(7): 385-418.

Lindberg, S.O. (1878) Utkast till en Naturlig Gruppering af Europas Bladmossor. J. C. Frenckell \& Sons, Helsinki, 39 pp.

Magill, R.E. (1981) Bryophyta, Part 1 Mosses, Fascicle 1 Sphagnaceae-Grimmiaceae. In: Leistner, O.A. (ed.) Flora of Southern Africa. Botanical Research Institute, Pretoria, $291 \mathrm{pp}$.

Matteri, C.M. (1985) Catálogo de los musgos. In: Boelcke, O., Moore, D.M. \& Roig, F.A. (eds.) Transecta Botánica de la Patagonia Austral, 11.2. CONICET, Buenos Aires, pp. 265-298.

Matteri, C.M. (2003) Los musgos (Bryophyta) de Argentina. Tropical Bryology 24: 33-100.

Matteri, C.M. \& Schiavone, M.M. (2002) Catálogo de los musgos (Bryophyta) de la Región Fueguina en Argentina y Chile. Revista del Museo Argentino de Ciencias Naturales, n.s. 4: 111-138.

McNeill, J., Barrie, F.R., Buck, W.R., Dmoulin, V., Greuter, W., Hawksworth, D.L., Herendeen, P.S., Knapp, S., Marhold, K., Prado, J., Prud'homme Van Reine, W.F., Smith, G.F., Wiersema, J.H. \& Turland, N.J. (eds.) (2012) International Code of Nomenclature for algae, fungi, and plants (Melbourne Code) adopted by the Eighteenth International Botanical Congress, Melbourne, Australia, July 2011. Regnum Vegetabile 154.

Menzel, M. (1992) Preliminary checklist of the mosses of Peru (Studies on Peruvian Bryophytes IV). Journal of the Hattori Botanical Laboratory 71: 175-254.

Mitten, W. (1851) Catalogue of cryptogamic plants collected by Professor W. Jameson in the vicinity of Quito. Hooker's Journal of Botany and Kew Garden Miscellany 3: 49-57.

Mitten, W. (1859) Musci Indiae Orientalis, an enumeration of the mosses of the East Indies. Journal of the Proceedings of the Linnean Society, Botany, Supplement 1: 1-96. http://dx.doi.org/10.1111/j.1095-8339.1859.tb02466.x

Mitten, W. (1869) Musci Austro-Americani. Journal of the Linnean Society, Botany 12: 1-659. http://dx.doi.org/10.1111/j.1095-8339.1871.tb00633.x

Montagne, C. (1850) Plantas Celulares. I. Musgos. In: Gay, C, (ed.) Historia Física y Política de Chile, 7. Privately published, Paris. 
Müller, C. (1847) De muscis nonnullis novis vel minus cognitis exoticis. Botanische Zeitung (Berlin) 5: 801-806, 825830.

Müller, C. (1849) Synopsis muscorum frondosorum omnium hucusque cognitorum, 1. A. Foerstner, Berlin, 812 pp.

Müller, C. (1879a) Musci Fendleriani Venezuelenses. Linnaea 42: 480.

Müller, C. (1879b) Prodromus bryologiae Argentinicae. I. Linnaea 42: 217-486.

Müller, C. (1882) Prodromus Bryologiae Argentinicae II, seu Musci Lorentziani Argentinici. Linnaea 43: 341-486.

Müller, C. (1897a) Musci venezuelenses novi a Professore C. Goebel collecti. Flora 83: 327-341.

Müller, C. (1897b) Prodromus bryologiae Bolivianae. Nuovo Giornale Botanico Italiano, n.s. 4(2): 113-172.

Müller, C. (1900) Genera muscorum frondosorum. Verlag von Eduard Kummer, Leipzig, 474 pp.

Müller, F. (2009) An updated checklist of the mosses of Chile. Archive for Bryology 58: 1-124.

Nees von Essenbeck, C.G.D. \& Hornschuch, C.F. (1823) Gymnostomum. In: Nees von Essenbeck, C.G.D., Hornschuch, C.F. \& Sturm, J. Bryologia Germanica 1, F. Fleischer, Leipzig, pp. 112-187.

O'Shea, B.J. (2006) Checklist of the mosses of sub-Saharan Africa (version 5). Tropical Bryology Research Reports 6: $1-252$.

Paris, É.G. (1894-1898) Index Bryologicus sive enumeratio muscorum hucusque cognitorum adjunctis synonyma distributioneque geographica locupletissimis quem conscripsit E. G. Paris. P. Klincksieck, Paris.

Paris, É.G. (1903-1906) Index Bryologicus sive enumeratio muscorum ad diem ultimam anni 1900 cognitorum adjunctis synonymia distributioneque geographica locupletissimis. Editio secunda. Libraire Scientifie A. Hermann, Paris.

Podpěra, J. (1954) Conspectus Muscorum Europaeorum. Nakladatelstvi Československe Akademie Věd, Praha, 697 pp.

Robinson, H. (1971) A revision of the moss genus, Hymenostyliella, with description of sporophyte. Phytologia 21: 1-3.

Ros, R.M., Cano, M.J., \& Guerra, J. (1999) Bryophyte checklist of Northern Africa. Journal of Bryology 21: 207-244.

Saito, K. (1975) A monograph of Japanese Pottiaceae (Musci). Journal of the Hattori Botanical Laboratory 39: 373537.

Sastre-De Jesús, I., Pérez Pérez, M. \& Motito Marín, Á. (2010) Mosses of the Dominican Republic: species catalogue, elevation distribution and floristic affinities. Harvard Papers in Botany 15(2): 415-446. http://dx.doi.org/10.3100/025.015.0217

Schimper, W.P. (1876) Synopsis Muscorum Europaeorum, editio Secunda. E. Schweizerbart, Stuttgardt, 886 pp.

Schliephacke, K. (1885) Zweie neue Laubmoose aus der Sweitz. Flora 68: 359-365.

Schwägrichen, C.F. (1811) Species Muscorum Frondosorum, Supplementum Primum. J.A. Barth, Leipzig, pp. xvi, 196, pl. 1-49.

Schwägrichen, C.F. (1823) Species Muscorum Frondosorum, Supplementum Secundum sect. 1. J.A. Barth, Leipzig, pp. i-vi, 1-86, pl. 101-125.

Schwägrichen, C.F. (1827) Species Muscorum Frondosorum, Supplementum Secundum sect. 2, vol. 2. J.A. Barth, Leipzig, pp. 81-210, pl. 176-200.

Sharp, A., Crum, H. \& Eckel, P.M. (1994) The moss flora of Mexico, vol. 1. Memoirs of the New York Botanical Garden 69: $1-580$.

Smith, J.E. (1804) Flora Britannica 3. J. Davis, London, pp. 915-1407.

Smith, A.J.E. (2004) The Moss Flora of Britain and Ireland. Second edition. Cambridge University Press, Cambridge, England, $1012 \mathrm{pp}$.

Sollman, P. \& Schäfer-Verwimp, A. (2012) Anoectangium stracheyanum Mitt. In: Ellis, L.T. et al. New national and regional bryophyte records, 32. Journal of Bryologist 34(3): 231-232. http://dx.doi.org/10.1179/1743282012Y.0000000019

Staples, G.W., Imada, C.T., Hoe, W.J. \& Smith, C.W. (2004) A revised checklist of Hawaiian mosses. Tropical Bryology 25: $35-70$.

Steere, W.C. (1936) Mosses of the G. Allan Hancock Expedition of 1934, collected by WM R. Taylor. Hancock Pacific Expeditions 3(1): 1-13.

Steere, W.C. (1948) Contribution of the bryogeography of Ecuador. I. A review of the species of Musci previously reported. The Bryologist 51: 65-167.

Streimann, H. \& Curnow, J. (1989) Catalogue of mosses of Australia and its external territories. Australian Flora and Fauna Series 10: 1-479.

Sullivant, W.S. (1859) United States Exploring Expedition, Musci. C. Sherman \& Son, Philadelphia, 32 pl.

Tan, B.C. \& Iwatsuki, Z. (1991) A new annotated Philippine moss checklist. Harvard Papers in Botany 3: 1-64.

Weber, W.A (1975) Additions to the bryoflora of the Galapagos Islands. Lindbergia 3: 79-82.

Werner, O., Ros, R.M. \& Grundman, M. (2005) Molecular phylogeny of Trichostomoideae (Pottiaceae, Bryophyta) based on nrITS sequence data. Taxon 54: 361-368.

http://dx.doi.org/10.2307/25065364

Wijk, R. v. d. \& Margadant, W.D. (1968) New combinations in mosses IX. Taxon 17: 467.

Williams, R.S. (1927) Mosses from Peru collected by the Captain Marshall Field Peruvian Expedition, 1923. Publications of the Field Museum of Natural History, Botanical Series 4(5): 125-139. 
Xing-jiang, L. \& Iwatsuki, Z. (1997) Revision of the genus Anoectangium from China. Acta Botanica Yunnanica 19: $243-250$.

Xing-jiang, L., Crosby, M.R. \& He, S. (2001) Moss flora of China, English version, vol. 2. FissidentaceaePtychomitriaceae. Science Press \& Missouri Botanical Garden Press, Beijing-St. Louis, 283 pp.

Yano, O. (2011) Catálogo de musgos brasileiros. Literatura original, basiônimo, localidade-tipo e distribuição geográfica. Instituto de Botanica, Secretaria do Meio Ambiente, São Paulo, 180 pp.

Yano, O. \& Bastos, C.J.P. (2004) Adições à flora de briófitas de Mato Grosso do Sul, Brasil. Acta Botanica Brasilica 18: 437-458. http://dx.doi.org/10.1590/s0102-33062004000300005

Zander, R.H. (1977) The tribe Pleuroweisieae (Pottiaceae, Musci) in Middle America. The Bryologist 80: $233-269$. http://dx.doi.org/10.2307/3242469

Zander, R.H. (1978a) Synopsis of the genus Tuerckheimia (Pottiaceae). Miscellanea Bryologica et Lichenologica 8: 2528.

Zander, R.H. (1978b) New combinations in Didymodon (Musci) and a key to the taxa of North America north of Mexico. Phytologia 41: 11-32.

Zander, R.H. (1993) Genera of the Pottiaceae: mosses of harsh environments. Bulletin of the Buffalo Society of Natural Sciences 32: 1-378.

Zander, R.H. (2006) The Pottiaceae s. str. as an evolutionary Lazarus taxon. Journal of the Hattori Botanical Laboratory 100: 581-602.

Zander, R.H. (2007) Molendoa. In: Flora of North America Editorial Committee (eds.) Flora of North America North of Mexico. Oxford University Press, New York, 27: 561-565.

Zander, R.H. \& Eckel, P.M. (1982) Hymenostylium recurvirostrum var. insigne and Barbula amplexifolia in British Columbia, Canada. Canadian Journal of Botany 60: 1596-1600. http://dx.doi.org/10.1139/b82-205

Zander, R.H. \& Eckel, P.M. (2007a) Gymnostomum. In: Flora of North America Editorial Committee (eds.) Flora of North America North of Mexico. Oxford University Press, New York, 27: 534-538.

Zander, R.H. \& Eckel, P.M. (2007b) Anoectangium. In: Flora of North America Editorial Committee (eds.) Flora of North America North of Mexico. Oxford University Press, New York, 27: 520-522.

Ziemmeck, F. \& Harpel, J. (2013) CDF Checklist of Galapagos Mosses. In: Bungartz, F., Herrera, H., Jaramillo, P., Tirado, N., Jiménez-Uzcátegui, G., Ruiz, D., Guézou, A. \& Ziemmeck, F. (eds.) Charles Darwin Foundation Galapagos Species Checklist. Charles Darwin Foundation, Puerto Ayora, Galapagos. Available from: http:// checklists.datazone.darwinfoundation.org/bryophytes/musci/ (accessed 17 January 2013). 